\title{
Dynorphin induces task-specific impairment of memory
}

\author{
INES B. INTROINI-COLLISON and LARRY CAHILL, \\ University of California, Irvine, California \\ CARLOS M. BARATTI \\ Universidad de Buenos Aires, Buenos Aires, Argentina \\ and \\ JAMES L. MCGAUGH \\ University of California, Irvine, California
}

\begin{abstract}
Immediate posttraining administration of the opioid peptide dynorphin(1-13) $(0.1,0.3$, and $1.0 \mu \mathrm{g} / \mathrm{kg}$ i.p.) significantly impaired $24-\mathrm{h}$ retention of a one-trial inhibitory avoidance task in mice. In contrast, posttraining dynorphin did not modify retention of either a Y-maze discrimination $(0.1,1.0$, or $10.0 \mu \mathrm{g} / \mathrm{kg}$ i.p.) or habituation of exploration $(0.1,0.3,1.0$, or $2.0 \mu \mathrm{g} / \mathrm{kg}$ i.p.). The administration of dynorphin $(0.1,1.0$, and $10.0 \mu \mathrm{g} / \mathrm{kg}$ i.p.) $2 \mathrm{~min}$ prior to the inhibitory avoidance retention test did not modify retention latencies of mice injected with either saline or dynorphin $(0.1 \mu \mathrm{g} / \mathrm{kg}$ i.p.) immediately after training. In mice, dynorphin appears to impair retention by interfering with memory storage processes, and this effect seems to be task specific.
\end{abstract}

There are three families of opioid peptides in the brain: the $\beta$-endorphins, the enkephalins, and the dynorphins (Akil et al., 1984; Weber, Evans, \& Barchas, 1983). Reports from many different laboratories have shown that in rats and mice posttraining administration of $\beta$-endorphin or the enkephalins produces retrograde amnesia in a wide variety of tasks (for reviews, see Introini \& Baratti, 1984; Izquierdo, 1982; Izquierdo \& Netto, 1985a, 1985b; McGaugh, 1983). Furthermore, a number of studies have reported that the posttraining memory-impairing effect of $\beta$-endorphin and the enkephalins can be reversed by the administration of these substances prior to the retention testing.

There are conflicting reports on the effects of posttraining administration of the $x$-agonist dynorphin on memory. Izquierdo, de Almeida, and Emiliano (1985) found that posttraining intraperitoneal administration of a wide range of doses of dynorphin does not affect retention of shuttle avoidance or step-down inhibitory avoidance in rats. Furthermore, Tilson, McLamb, and Hong (1986) reported that retention in rats was not altered by posttraining intracerebroventricular injections of dynorphin. In contrast, Introini (1984) found that posttraining dynorphin produces retrograde amnesia in a one-trial step-through task in mice, at dose levels $(0.01-3.00 \mu \mathrm{g} / \mathrm{kg})$ well within the

Preparation of this paper was supported in part by USPHS Research Grants MH 12526 and AG00538 and Contract N00014-84-K-0391 from the Office of Naval Research (to J.L.McG.). Address correspondence to Ines B. Introini-Collison, Center for the Neurobiology of Learning and Memory, University of California, Irvine, CA 92717. range studied by Izquierdo et al. (1985). Interestingly, Castellano and Pavone (in press) showed that posttraining administration of the $\mathcal{x}$-opioid receptor agonist bremazocine impairs retention of an inhibitory avoidance task in DBA/2 mice, and that this effect is time- and dosedependent. The amnestic effect of bremazocine appears to be a consequence of activation of $x$-receptors, since it is prevented by the administration of an ineffective dose of the $x$-receptor antagonist MR-1452. The discrepancy between these two sets of findings could be due to a number of factors. First, there may be strain or species differences in sensitivity to dynorphin and $x$-agonists. Castellano and Pavone (personal communication, 1986) reported that the $x$-agonist $U-50,488$ impairs retention of an inhibitory avoidance task when administered to DBA mice, but facilitates memory in C57 mice. A second possibility is that the effect of dynorphin on memory may be task specific. Jefferys, Boublik, and Funder (1985), for example, reported that the impairment of retention produced by adrenalectomy in rats is attenuated by posttraining administration of several $x$-selective agonists, including dynorphin(1-17).

It is not known whether dynorphin is released during training or whether it causes the release of brain $\beta$ endorphin (Izquierdo, 1982). However, if dynorphin effects on memory in mice involve the same physiological mechanisms that are influenced by $\beta$-endorphin (or indirectly by the enkephalins), dynorphin should impair retention when administered posttraining and enhance retention when administered prior to the retention test. The present study was undertaken to examine this possibility. 


\section{METHOD}

Male CFW mice (Charles River) weighing 23-28 g were used to investigate the effects of immediate posttraining administration of $0.1,0.3$, or $1.0 \mu \mathrm{g} / \mathrm{kg}$ of dynorphin(1-13) (Sigma) on retention performance in a one-trial step-through inhibitory avoidance task (lzquierdo \& McGaugh, 1985; McGaugh \& Landfield, 1970), a Y-maze discrimination (Introini-Collison \& McGaugh, 1986), and a habituation task (Izquierdo \& Netto, 1985b). We also examined the effect of dynorphin $(0.1,1.0$, or $10.0 \mu \mathrm{g} / \mathrm{kg}, 2 \min$ prior to test) on retention of inhibitory avoidance in mice that had been injected with either physiological saline or dynorphin $(0.1 \mu \mathrm{g} / \mathrm{kg}) \mathrm{im}$ mediately after training. Dynorphin was dissolved in saline to an injection volume of $10.0 \mathrm{ml} / \mathrm{kg}$. Control animals received saline. Animals were randomly assigned to the treatment groups $(n=12)$ in each of the three experiments.

\section{Inhibitory Avoidance Task}

The mice were first trained individually on a trough-shaped stepthrough inhibitory avoidance apparatus (McGaugh \& Landfield, 1970). On the training trial, the mouse was placed in the lighted compartment, facing away from the dark compartment, and a door leading to the dark compartment was opened. When the mouse stepped through the door into the dark compartment the door was closed and a footshock $(0.7 \mathrm{~mA}, 60 \mathrm{~Hz}, 2 \mathrm{sec})$ was delivered. The mouse was then immediately removed from the apparatus and injected intraperitoneally with saline or $0.1,0.3$, or $1.0 \mu \mathrm{g} / \mathrm{kg}$ of dynorphin. On the retention test $24 \mathrm{~h}$ later, the mouse was placed in the lighted compartment, as on the training session, and its latency to reenter the dark compartment (maximum of $300 \mathrm{sec}$ ) was recorded.

\section{Y-Maze Discrimination Task}

One week after completion of inhibitory avoidance training, the mice were assigned to new treatment groups counterbalanced on the basis of previous treatments, and were individually trained on a Y-maze discrimination task (Introini-Collison \& McGaugh, 1986). For both training and testing, the end of the left alley of the $\mathrm{Y}$-maze was illuminated, while the starting alley and the right alley were not illuminated. On the first training trial, the mouse was placed in the starting alley and the sliding door of the alley was opened, while the door leading to the right alley remained closed. After $10 \mathrm{sec}$, a footshock $(0.3 \mathrm{~mA}, 60 \mathrm{~Hz})$ was delivered and remained on until the mouse escaped into the left (illuminated) alley. The response latencies were less than $10 \mathrm{sec}$ in almost all cases. If the mouse failed to escape within $60 \mathrm{sec}$, it was placed into the safe compartment. After an intertrial interval (ITI) of $40 \mathrm{sec}$, the mouse was placed in the start compartment and given a forced trial to the right (darkened) alley, where the footshock was delivered for an additional $5 \mathrm{sec}$. On subsequent trials (20-sec ITI), the mouse was allowed to choose between the two alleys. The mice were trained to a criterion of three successive choices of the left alley.

On the 24-h retention test, the discrimination was reversed: the right, dark alley was now the safe compartment. On each of six trials (20-sec ITI), the mouse was placed in the start compartment, the sliding door was opened, and after $10 \mathrm{sec}$ a footshock was delivered, lasting until the mouse escaped into the right arm of the maze. The number of errors (choices of the left alley) was recorded as the measure of retention.

In previous research (Introini-Collison \& McGaugh, 1986), we found that errors on reversal training were increased as a function of the amount of training on Day 1 . Furthermore, we found that retention was enhanced (i.e., errors on the reversal task increased) by posttraining administration of naloxone or low doses of epinephrine (Epi) but impaired (i.e., reversal errors decreased) by $\beta$-endorphin or high doses of Epi (Introini-Collison \& McGaugh, 1987).
Table 1

Effect of Posttraining Administration of Dynorphin (DYN) on Latencies to Step Through During the Retention Test

\begin{tabular}{lcc} 
& \multicolumn{2}{c}{ Retention Latencies (sec) } \\
\cline { 2 - 3 } Treatment & Median & Interquartile Range \\
\hline Saline & 83.0 & $37.0-300.0$ \\
DYN $0.1 \mu \mathrm{g} / \mathrm{kg}$ & 9.9 & $5.5-24.0^{*}$ \\
DYN $0.3 \mu \mathrm{g} / \mathrm{kg}$ & 10.5 & $6.0-14.5 \dagger$ \\
DYN $1.0 \mu \mathrm{g} / \mathrm{kg}$ & 13.5 & $9.5-17.5^{*}$ \\
\hline Note
\end{tabular}

$\overline{\text { Note}}-N=12$ mice per group. $\quad{ }^{*} p<.01$ and $\dagger p<.001$, as compared with the saline-injected control group.

\section{Habituation of Exploration}

Different mice were used for the habituation task. The testing chamber was a glass container $(39 \times 20 \times 25 \mathrm{~cm})$, with the floor of the container divided into six compartments $(10 \times 13 \mathrm{~cm}$ each). For both the training trial (initial exploration) and the testing trial $24 \mathrm{~h}$ later, the mouse was placed in a corner of the chamber facing the wall (the same compartment was used for all the animals and for both training and testing). The mouse was allowed to explore the chamber for a period of $3 \mathrm{~min}$, and the number of compartments entered with all four paws was recorded. Immediately posttraining, mice were injected with saline or dynorphin $(0.1,0.3,1.0$, or $2.0 \mu \mathrm{g} / \mathrm{kg}$ ) and returned to their home cages (6 per cage).

\section{Data Analysis}

Data were analyzed with the Mann-Whitney $U$ test; $p$ values of less than .05 were considered significant.

\section{RESULTS}

\section{Inhibitory Avoidance}

Table 1 shows that-in accordance with previous findings in mice (Introini, 1984), and in disagreement with the findings of Izquierdo et al. (1985), who used ratsthe posttraining administration of dynorphin $(0.1,0.3$, and $1.0 \mu \mathrm{g} / \mathrm{kg}$ ) significantly impaired retention in the stepthrough inhibitory avoidance task. Comparable effects were seen at all three doses of dynorphin.

On the other hand, the data in Table 2 show that administration of dynorphin prior to the retention test, at a dose level between 0.1 and $10.0 \mu \mathrm{g} / \mathrm{kg}$, had no effect on retention latencies of animals given posttraining injections of either saline or dynorphin. It is worth noting that

Table 2

Effect of Dynorphin (DYN) Administered $2 \mathrm{~min}$ Before Testing on Latencies to Step Through During the Retention Test of Mice Injected With Saline or Dynorphin $(0.1 \mu \mathrm{g} / \mathrm{kg})$ Immediately Posttraining

\begin{tabular}{ccccc}
\multicolumn{2}{c}{ Treatment } & & \multicolumn{2}{c}{ Retention Latencies $(\mathrm{sec})$} \\
\cline { 5 - 5 } Posttraining & \multicolumn{1}{c}{ Pretest } & & Median & Interquartile Range \\
\cline { 1 - 2 } Saline & Saline & & 44.5 & $20.5-300.0$ \\
Saline & DYN $(0.1 \mu \mathrm{g} / \mathrm{kg})$ & & 52.0 & $16.0-276.0$ \\
Saline & DYN $(1.0 \mu \mathrm{g} / \mathrm{kg})$ & & 38.5 & $18.0-300.0$ \\
Saline & DYN $(10.0 \mu \mathrm{g} / \mathrm{kg})$ & 65.5 & $20.0-300.0$ \\
DYN & Saline & 3.0 & $2.5-8.0^{*}$ \\
DYN & DYN $(0.1 \mu \mathrm{g} / \mathrm{kg})$ & 5.0 & $3.5-6.0^{*}$ \\
DYN & DYN $(1.0 \mu \mathrm{gg} / \mathrm{kg})$ & 6.0 & $3.5-8.5^{*}$ \\
DYN & DYN $(10.0 \mu \mathrm{g} / \mathrm{kg})$ & 5.5 & $3.5-8.5^{*}$ \\
\hline
\end{tabular}

Note $-N=12$ mice per group. ${ }^{*} p<.001$, as compared with the group that received saline posttraining and the same treatment pretest (MannWhitney $U$ tests, one-tailed). 
Table 3

Effect of Immediate Posttraining Dynorphin (DYN) on Retention of the Y-Maze Visual Discrimination Task

\begin{tabular}{lcc}
\hline & \multicolumn{2}{c}{ Errors on Reversal } \\
\cline { 2 - 3 } Treatment & Mean & SEM \\
\hline Saline & 2.67 & 0.28 \\
DYN $0.1 \mu \mathrm{g} / \mathrm{kg}$ & 2.33 & 0.36 \\
DYN $0.3 \mu \mathrm{g} / \mathrm{kg}$ & 2.75 & 0.35 \\
DYN $1.0 \mu \mathrm{g} / \mathrm{kg}$ & 2.83 & 0.46 \\
\hline
\end{tabular}

Note- $N=12$ mice per group.

for animals given posttraining dynorphin, the administration of dynorphin prior to the retention test had no effect on retention performance even at a dose 100 times higher than that administered immediately after training.

\section{Y-Maze Discrimination}

Different results were obtained when dynorphin was injected after training on the $\mathrm{Y}$-maze discrimination task. Table 3 shows the mean number of errors made by each of the groups over the six reversal trials. As is apparent from the table, posttraining administration of dynorphin did not affect retention of the reversal discrimination.

\section{Exploration}

The results of this experiment, expressed as the average decrease in exploration (training-testing), are shown in Table 4. For all groups, the exploratory behavior of the mice decreased from the first to the second exposure to the chamber $(p<.05)$. This decrease in exploration was not affected by posttraining administration of dynorphin.

\section{DISCUSSION}

The present findings indicate that the effects of dynorphin on memory differ from those of $\beta$-endorphin or the enkephalins in several respects. First, and most important, the effects of dynorphin on memory are task dependent. Dynorphin significantly impaired retention of the inhibitory avoidance task. These results are in agreement with observations previously reported by one of us in a similar experimental situation (Introini, 1984), but do not agree with observations made by other investigators (Izquierdo et al., 1985; Tilson et al., 1986) working with rats in a shuttle avoidance or a step-down inhibitory avoidance task. Since dynorphin was injected systemically in our ex-

Table 4

Effect of Posttraining Administration of Dynorphin (DYN) on Decrease in Exploration (Training - Testing)

Decrease in Exploration

(Lines Crossed)

\begin{tabular}{llll}
\cline { 2 - 4 } \multicolumn{1}{c}{ Treatment } & Mean & SEM & $N$ \\
\hline Saline & 19.15 & 4.07 & 13 \\
DYN $0.1 \mu \mathrm{g} / \mathrm{kg}$ & 21.86 & 3.99 & 14 \\
DYN $0.3 \mu \mathrm{g} / \mathrm{kg}$ & 19.86 & 4.19 & 14 \\
DYN $1.0 \mu \mathrm{g} / \mathrm{kg}$ & 29.67 & 3.90 & 15 \\
DYN $2.0 \mu \mathrm{g} / \mathrm{kg}$ & 27.33 & 4.83 & 15 \\
\hline
\end{tabular}

periments, whereas Tilson et al. (1986) administered the drug intracerebroventricularly, it is tempting to suggest that the effect of dynorphin on memory may be due to peripheral influences. However, other investigators using rats observed no effect of dynorphin when the drug was injected systemically (Izquierdo et al., 1985). Thus, the available evidence indicates that dynorphin does not impair memory in rats, whether administered centrally (Tilson et al., 1986) or systemically (Izquierdo et al., 1985), but does induce amnesia in mice. Interestingly, Castellano and Pavone (in press) found that other $x$-agonists induce amnesia in two different strains of mice.

Unlike the effects seen with $\beta$-endorphin, the impairing effect of dynorphin in the inhibitory avoidance task was not reversed by another injection of dynorphin given prior to testing. Likewise, the administration of dynorphin just prior to the retention test did not affect retention in control animals. The postraining amnestic effect of dynorphin therefore cannot be explained by the induction of state dependency (Izquierdo, 1980; Izquierdo \& Dias, 1983, 1985; Izquierdo \& Netto, 1985b; Izquierdo \& McGaugh, 1985). Furthermore, unlike many other treatments, including the opioid peptides $\beta$-endorphin (Introini-Collison \& McGaugh, 1987) and metenkephalin (Zhang, McGaugh, Juler, \& Introini-Collison, in press), dynorphin has different effects in inhibitory avoidance and $Y$-maze discrimination tasks. In the latter, dynorphin does not modify retention. Similarly, dynorphin has no significant effect on habituation of exploration.

Jefferys et al. (1985) observed the dynorphin and the $\boldsymbol{x}$-agonist ketocyclazocine completely reverse the amnestic effect of adrenalectomy on a swimming task, an effect not observed with morphine or [D-Ala $\left.{ }^{2}, \mathrm{D}-\mathrm{Leu}^{\mathrm{S}}\right]$ enkephalin. In summary, the present findings argue against the hypothesis of a general effect of dynorphin in memory modulation. The effect of dynorphin or of $x$-agonists, in general, appears to be unlike the effect of the other opioids, since its effects are highly dependent on the task as well as on species of animals used.

\section{REFERENCES}

Akil, H., Watson, S., Young, E., Lewis, M. E., Kachaturian, H., \& WALKER, M. (1984). Endogenous opioids: Biology and function. Annual Review of Neuroscience, 7, 223-255.

Castellano, C., Pavone, F. (in press). Effects of bremazocine on passive avoidance behaviour in mice. Archives of Intermational Pharmacodymic.

InTroinı, I. B. (1984). Participación de peptidos opioides endogenos en el proceso de consolidación de la memoria. Su posible interacción con otros sistemas neuronales. Unpublished doctoral dissertation, University of Buenos Aires.

IntrolNI, I., \& BaratTI, C. M. (1984). The impairment of retention induced by beta-endorphin in mice may be mediated by reduction of central cholinergic activity. Behavioral \& Neural Biology, 41, 152-163.

Int RoINI-Collison, I. B., \& McGaugh, J. L. (1986). Epinephrine modulates long-term retention of an aversively-motivated discrimination task. Behavioral \& Neural Biology, 45, 358-365.

InTronn1-Collison, I. B., \& McGaUGH, J. L. (1987). Naloxone and beta-endorphin alter the effects of posttraining epinephrine on retention of an inhibitory avoidance response. Psychopharmacology. 
IZQUiERDo, I. (1980). Effect of beta-endorphin and naloxone on acquisition, memory and retrieval of shuttle avoidance and habituation learning in rats. Psychopharmacology, 69, 111-115.

IzQuierdo, I. (1982). Beta-endorphin and forgetting. Trends in Pharmacological Sciences, 3, 455-457.

IzQuierdo, I, DE Almeida, M. A. M. R., \& EMIliano, V. R. (1985). Unlike b-endorphin, dynorphin $(1-13)$ does not cause retrograde amnesia for shuttle avoidance or inhibitory avoidance learning in rats. Psychopharmacology, 87, 216-218.

IzQuiERDo, I., \& DiAs, R. D. (1983). Memory modulation by posttraining tyramine and guanethidine and their interaction with alphamethyl-p-throsine, naloxone and beta-endorphin. Arquivos de Biologia e Technologia, 26, 337-343.

IzQuiERDo, I., \& Dias, R. D. (1985). Influence on memory of posttraining and pre-test injections of ACTH, vasopressin, epinephrine, or B-endorphin, and their interaction with naloxone. Psychoneuroendocrinology, 10, 165-172.

IzQUIERDO, I., \& MCGAUGH, J. L. (1985). Effect of a novel experience prior to training or testing on retention of an inhibitory avoidance response in mice: Involvement of an opioid system. Behavioral \& Neural Biology, 44, 228-238.

IZQUIERDO, I., \& NeTTo, C. A. (1985a). The brain beta-endorphin system and behavior: The modulation of consecutively and simultaneously processed memories. Behavioral \& Neural Biology, 44, 249-265.
IzQuiERDo, I., \& NeTto, C. A. (1985b). The role of beta-endorphin in memory regulation. Annals of the New York Academy of Sciences, 444, 162-167.

JefFerys, D., Boublik, J., \& Funder, J. W. (1985). A $x$-selective opioidergic pathway is involved in the reversal of a behavioral effect of adrenalectomy. European Journal of Pharmacology, 107, 331-335.

McGaugh, J. L. (1983). Hormonal influences on memory. Annual Review of Psychology, 34, 297-323.

McGaugh, J. L., \& LANDField, P. W. (1970). Delayed development of amnesia following electroconvulsive shock. Physiology \& Behavior, 5, 1109-1111.

Tilson, H., McLamb, R., \& Hong, J. (1986). Behavioral effects of centrally administered dynorphin and [D-Ala ${ }^{2}$-D-Leu] enkephalin (dadle) in rats. Neuropeptides, 8, 193-206.

Weber, E., Evans, C. J., \& Barchas, J. D. (1983). Multiple endogenous ligands for opioid receptors. Trends in Neuroscience, $\mathbf{6}$, 333-336.

Zhang, S., McGaugh, J. L., Juler, R. J., \& Introini-Collison, I. (in press). Naloxone and met-enkephaline effects on retention: Attenuation by adrenal denervation. European Journal of Pharmacology.

(Manuscript received November 17, 1986; revision accepted for publication February 11, 1987.) 